\title{
Okul Öncesinde Drama Dersinin Üniversite Öğrencilerine Katkısının Bazı Değişkenlere Göre İncelenmesi
}

\author{
Şehnaz CEYLAN. Esra ÖMEROĞLU** \\ Gazi Üniversitesi
}

\begin{abstract}
Özet
Bu çalışma, okul öncesinde drama dersinin okul öncesi eğitimi öğretmenlik programındaki üniversite ögrrencilerine katkısının bazı değişkenlere göre incelenmesi amacıyla yapılmıştır. Araştırmanın örneklemini, Gazi Üniversitesi Eğitim Fakültesi ve Mesleki Eğitim Fakültesi, Ankara Üniversitesi Eğitim Fakültesi ve Hacettepe Üniversitesi Ĕ̆itim Fakültesi okul öncesi eğitim öğretmenliği programına devam eden 155 dördüncü sinıf öğrencisi oluşturmaktadır. Veri toplamak amaciyla, "Yaratıcı Drama Dersinin Öğrenciye Katkısın Değerlendirme Formu" kullanılmıştır. Toplanan veriler "Kruskall-Wallis Testi" ve "Mann Whitney U-Testi" ile analiz edilmişstir. Yaratıcı darama dersi alan ögrencilerin dersin kendilerine olan katkılarına ilişkin görüşlerinin yüzdelik değerleri ve medyan, minimum, maximum değerleri verilmiştir. Araștırma sonuçlarına göre, okul öncesi ĕgitimi öğretmenlik programındaki üniversite öğrencilerinin aldikları puanla, öğrencilerin devam ettikleri üniversiteleri, cinsiyetleri, yaşları, yaratıcı drama kurslarına katılma durumlarl, okul öncesinde drama dersinden başarlsız olma durumları ve okul öncesi drama eğitimi aldlkları ortamlar arasinda anlamlı bir farklllık görülmemektedir. Ancak, okul öncesinde drama dersini ikinci kez seçmeli olarak alanlarla almayanlar arasinda, alanlar lehine anlamlı bir farklllı görülmektedir. Ayrıca, okul öncesinde drama dersi alan ögrencilerin forma verdikleri cevaplara göre yarıdan fazlasının yaratıcı drama ĕ̆itiminin kendilerine bir çok alanda katkı sağladığını belirtmişlerdir. Öğrencilerin okul öncesinde drama dersinin kendilerine olan katkılarına ilişskin görüşlerinin olumlu yönde olduğu bulunmuştur.
\end{abstract}

Anahtar sözcükler: Okul öncesinde drama, okul öncesi eğitim, ögrretmen adayı

\begin{abstract}
This study was conducted to examine the contribution of drama course at the teaching program of preschool education to university students. The sampling of the study consisted of 155 fourth grade students attending to the teaching program of preschool education at Gazi University, Faculty of Vocational Education, Ankara University Faculty of Education and Hacettepe University Faculty of Education. "The Evaluation Form for the Contribution of the Course of Creative Drama to Students" was used to collect data. The data collected was analyzed through "Kruskall - Wallis Test" and "Mann Whitney U - Test". Percentage values and median, minimum, maximum values of the ideas of the students taking the course of creative drama over its contribution to themselves were given. Depending on the results of the study, there was no significant difference between the scores of university students at the teaching program of preschool education and the universities they attend, their genders, ages, the status of participating the course of creative drama, the status of the failure at the course of creative drama and environment where they take the course of creative drama. In addition, more than half of the students expressed that the course of creative drama made a contribution on them in many respects, according to the answers of the students taking the course of creative drama to the form. It was also found that the ideas of the students over the contribution of the course of creative drama to them were positive.
\end{abstract}

Keywords: Drama at preschool education, preschool education, pre-service teacher

\footnotetext{
- Araş Gör., Gazi Üniversitesi, Mesleki Eğitim Fakültesi, Okul Öncesi Eğitimi Anabilim Dall, E-posta: sehnazc@gmail.com

*** Prof. Dr., Gazi Üniversitesi, Mesleki Eğitim Fakültesi, Okul Öncesi Eğitimi Anabilim Dall, E-posta: esra.omeroglu@gmail.com
} 


\section{Giriş}

Günümüz eğitim yaklaşımlarında, öğretmenin rolü, öğrencilerine yeni bilgiler kazandırmanın yanı sıra, onların gelişim özellikleri doğrultusunda ilgi, istek ve yeteneklerini keşfetmek, neden sonuç ilişkilerini kurabilmelerini sağlamak, problem çözme becerilerini geliştirmek, iyi bir gözlemci olabilmelerini ve duygu, düşüncelerini çeşitli yollarla ifade edebilmelerini sağlamak, aynı zamanda grupla birlikte çalışmalarına imkan sağlayarak yaratıcı ve estetik bir bakış açısı kazanmalarına yardımcı olmaktır. Bu eğitim amaçlarına öğretmen çeşitli eğitim- öğretim yöntemleri ile ulaşabilir. Bu eğitim öğretim yöntemlerinden birisi de yaratıcı dramadır. Yaratıcı drama eğitimi yoluyla yaşantılara dayalı bilişsel, duyuşsal ve devinişsel alanlara yönelik öğrenme gerçekleşir (Genç, 2004, s.31; Kandır, 2003, s.22).

Eğitim alanında çalışan kişiler yaratıcı dramanın önemini vurgulamıştır. Dorothy Heathcote, dramanın eğitimde ve yaşantılara dayalı öğrenmede etkisini vurgulamış ve dramanın öğrenme için etkin bir yöntem olduğuna inanarak, dramayı "yaşamın pratiği” olarak açıklamıştır. Norman'a göre ise, drama kişinin evrensel, toplumsal, etik ve soyut kavramları anlamlandırmasıdır. Courtney de dramayı "iç dünya ile çevre arasındaki etkin bir köprü” olarak görmüştür. McCaslin yaratıcı dramanın, ilk olarak kişinin kendi benliğini anlamasına ve kabul edilmesine, daha sonra çevresindeki diğer kişileri kabul etmesine yardımcı olduğunu vurgulamıştır (Adıgüzel, 2006a:s.3; Freeman, Sullivan ve Fulton, 2003:s.131; San, 2002:s.65; Uysal, 1996:s.36).

Yapılan araştırmalar da, öğretim kademelerinin tüm basamaklarında yaratıcı drama eğitiminin öğrencilerin kendine ve karşısındakine güven duymasına, empati, iletişim ve problem çözme becerisini geliştirmesine, sosyal-duygusal yönden gelişmesine, çevresiyle olumlu ilişkiler kurabilmesine, yaratıcılı̆̆ını geliştirmesine yardımcı olduğu görülmektedir (Akoğuz, 2002; Erkan, 2005; Dikici, Gündoğdu ve Koç, 2003; Kara ve Çam, 2007; Metin, 1999; Okvuran, 1993; Yayla ve Ömeroğlu, 2005). Özellikle bu değerlerin kazandırılmasında erken çocukluk dönemi çok önemlidir. Çünkü, erken çocukluk tüm gelişimlerin en hızlı olduğu dönemdir.

$\mathrm{Bu}$ değerlerin çocuklara kazandırılabilmesi için okul öncesi eğitimi öğretmeninin de aynı değerlere sahip olması gerekmektedir. Üniversitelerde 1997 yılından itibaren eğitim fakültelerinin “Okul Öncesi Eğitimi Öğretmenliği” programlarında okul öncesinde drama dersi zorunlu ders olarak yer almıştır (Adıgüzel, 2006b, s.8). Okul öncesinde drama dersi programda artık 4. yarıyılda iki teorik iki uygulamalı olmak üzere haftada dört saat yer almaktadır. Okul öncesinde drama dersi, dramanın tanımını, drama türleri arasında fark ve benzerlikleri, tarihçeyi, oyun ve dramanın çocuk gelişimi ve eğitimindeki önemi ve yararlarını, drama tekniği, drama türlerini, okul öncesi eğitimde günlük ve 
haftalık plan içerisinde drama etkinliklerinin yerleştirilmesini içermektedir. Bu nedenle, okul öncesinde drama dersi, üniversitelerin okul öncesi eğitim öğretmenliği programlarındaki eğitim alan öğrencilere okul öncesinde dramayla ilgili bilgi ve becerilerin kazandırılmasını hedeflemektedir. Okul öncesi öğretmen adaylarının yaratıcı drama çalışmalarına katılımları öncelikle onların kişisel gelişimlerini desteklemektedir. Böylece, öğretmen adayları, okul öncesi eğitimde drama etkinliklerini planlama ve uygulama becerisini kazanmaktadır (Köksal-Akyol ve Çiftçibaşı, 2004). Ayrıca, okul öncesinde dramanın öneminin farkında olan öğretmen adayları öğretmen olduktan sonra kendini bu alanda geliştirerek, yaratıcı drama yoluyla çocuklarda problem çözme, empati, sosyal vb. becerilerin kazandırılmasına yardımcı olabilir. Okul öncesi öğretmen adaylarının bu becerileri kazanmasını bazı değişkenler etkileyebilir.

Öğretmen adaylarının okul öncesinde drama dersiyle ilgili görüşlerinin ve görüşlerinde bazı değişkenlerin etkili olup olmadığının bilinmesi dersi veren eğitimcilerin yaklaşımını da etkileyebilir. Böylece, eğitimciler dersi planlarken ve uygularken öğrencilerin dersle ilgili görüşlerini etkileyen değişkenleri dikkate alabilir. $\mathrm{Bu}$ da, eğitimcinin öğrencilere karşı olumlu bir tutum içinde olmasını sağlayabilir.

$\mathrm{Bu}$ nedenle çalışmanın amacı, okul öncesi eğitimi öğretmenlik programına devam eden öğretmen adaylarına okul öncesinde drama dersinin katkısının olup olmadığının devam ettiği üniversite, cinsiyet, yaş, yaratıcı drama kurslarına katılma durumu, yaratıcı drama dersinden başarılı olup olmama durumu, okul öncesinde drama dersini tekrar seçmeli ders olarak alıp almama durumu ve yaratıcı drama eğitimini aldığı ortam değişkenlerine göre incelemektir.

\section{Yöntem}

Bu bölümde araştırmanın örneklemi, veri toplama araçları ve işlem basamakları yer almaktadır.

\section{Örneklem}

$\mathrm{Bu}$ çalışma, okul öncesi eğitim öğretmeni yetiştiren Gazi Üniversitesi Eğitim Fakültesi ve Mesleki Eğitim Fakültesi, Ankara Üniversitesi Eğitim Bilimleri Fakültesi ve Hacettepe Üniversitesi Eğitim Fakültesi'nde gerçekleştirilmiştir. Bu dört fakültenin Okul Öncesi Eğitim Öğretmenliği programlarına devam eden ve okul öncesinde drama dersi almış olan 155 dördüncü sınıf öğrencisi araştırmanın örneklemini oluşturmuştur.

\section{Veri Toplama Aracı}

Veri toplamak amacıyla, öğrencilerin yaşı, cinsiyeti, devam ettikleri üniversite, en uzun yaşadıkları yerleşim merkezi, anne babalarının yaşı ve eğitim düzeyi gibi demografik özellikleri belirlemek için 
"Kişisel Bilgi Formu”, öğrencilerin okul öncesinde drama dersinin kendilerine katkısını değerlendirmeleri amacıyla ise araştırmacılar tarafından hazırlanan, "Okul Öncesinde Drama Dersinin Öğrenciye Katkısını Değerlendirme Formu” kullanılmıştır. Formun maddelerini belirleme aşamasında, alanyazın gözden geçirilmiş ve bu konuda gerçekleştirilmiş araştırmalar incelenmiştir. $\mathrm{Bu}$ form, toplam 30 maddeden oluşmaktadır. Hazırlanan 30 madde, alanla ilgili uzmanların görüşüne sunularak anlatımda bir eksiklik ya da yanlış anlamaya yol açabilecek bir karmaşa olup olmadığı kontrol edilmiştir. Öğrenciler, bu maddelere "Tamamen Katılıyorum”, "Katılıyorum”, "Kararsızım”, “Katılmıyorum”, “Kesinlikle Katılmıyorum” biçiminde 5'li derecelendirme şeklinde işaretleyerek cevap vermektedir. Puanlama ise, "Kesinlikle katılıyorum" dan başlayarak 5'ten 1'e kadar sıralanmıştır. Hazırlanan formdaki tüm maddeler olumlu ifadeler olarak hazırlanmıştır. Öğrencilerin bu formdan alacakları en yüksek puan 150 ve en düşük puan 30 olarak hesaplanmıştır. Eğer öğrenciler formdaki maddelere "Tamamen Katılıyorum" şeklinde cevap vermişlerse 150 puan almaktadır. Buna göre, öğrencilerin verdiği diğer cevaplara göre puanları değişmektedir.

\section{İşlem}

Okul Öncesinde Drama Dersinin Öğrenciye Katkısını Değerlendirme Formu, 2006-2007 eğitim öğretim döneminde, Gazi Üniversitesi Eğitim Fakültesi ve Mesleki Eğitim Fakültesi, Ankara Üniversitesi Eğitim Bilimleri Fakültesi ve Hacettepe Üniversitesi Eğitim Fakültesi Okul Öncesi Eğitim Öğretmenliği programında okul öncesinde drama dersi almış öğrencilere araştırmacılar tarafından sınıf ortamında uygulanmıştır.

Örnekleme alınan gruplardan elde edilen veriler, SPSS istatistik programı kullanılarak analiz edilmiştir. Toplanan veriler, incelenen bağımsız değişkenlere göre analiz edilmiş ve bu analizlerde "Kruskall-Wallis Testi (Ki-Kare)" ve "Mann Whitney U-Testi” kullanılmıştır. Yaratıcı darama dersi alan öğrencilerin dersin kendilerine olan katkılarına ilişkin görüşlerinin yüzdelik değerleri ve medyan, minimum, maximum değerleri verilmiştir.

\section{Bulgular ve Yorum}

Örneklemde yer alan öğrencilerin devam ettikleri üniversite, yaş grupları, cinsiyetleri, en uzun yaşadıkları yerleşim merkezine, anne-baba yaş grupları ve anne -baba öğrenim düzeyine ait bilgiler şekil 1- 6 arasında verilmiştir. Değişkenlere göre Okul Öncesinde drama dersine katılan öğrencilerin aldıkları puanların karşılaştırma sonuçları ise Tablo 1- 7 arasında verilmiştir. Okul öncesinde drama dersi alan öğrencilerin dersin kendilerine olan katkılarına ilişkin görüşlerinin yüzdelik değerleri ve medyan, minimum, maximum değerleri tablo 8- 9' da verilmiştir. 


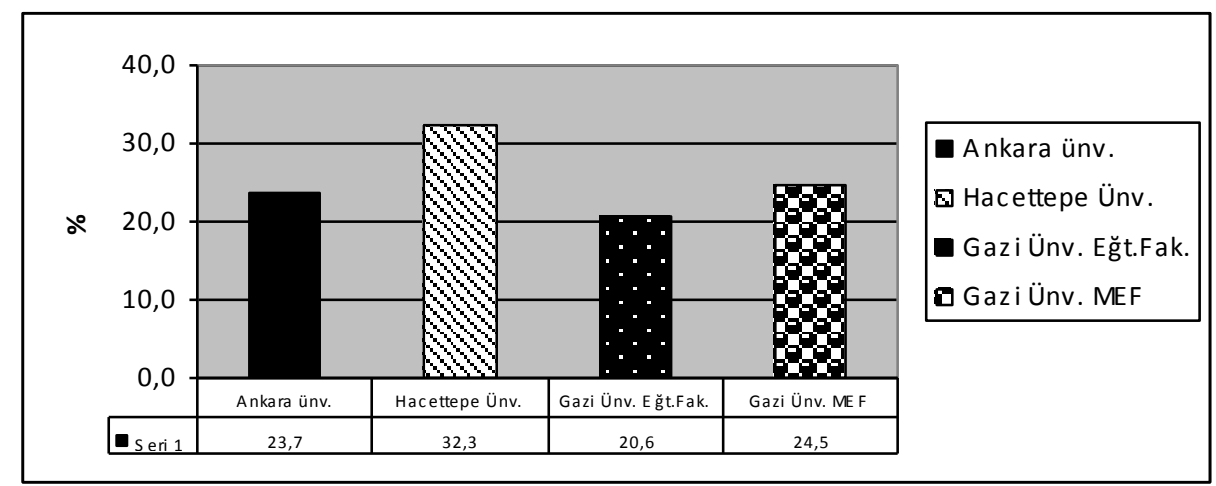

Şekil 1 Uygulama Yapılan Üniversitelerin Dă̆llımları

Şekil 1'de görüldüğü gibi, araştırmaya dahil edilen öğrencilerin üniversitelere göre dağılımları \%23.7 Ankara Üniversitesi Eğitim Bilimleri Fakültesi, \% 32.3 Hacettepe Üniversitesi Eğitim Fakültesi, \% 20.6 Gazi üniversitesi Eğitim Fakültesi, \% 24.5 Gazi Üniversitesi Mesleki Eğitim Fakültesidir.

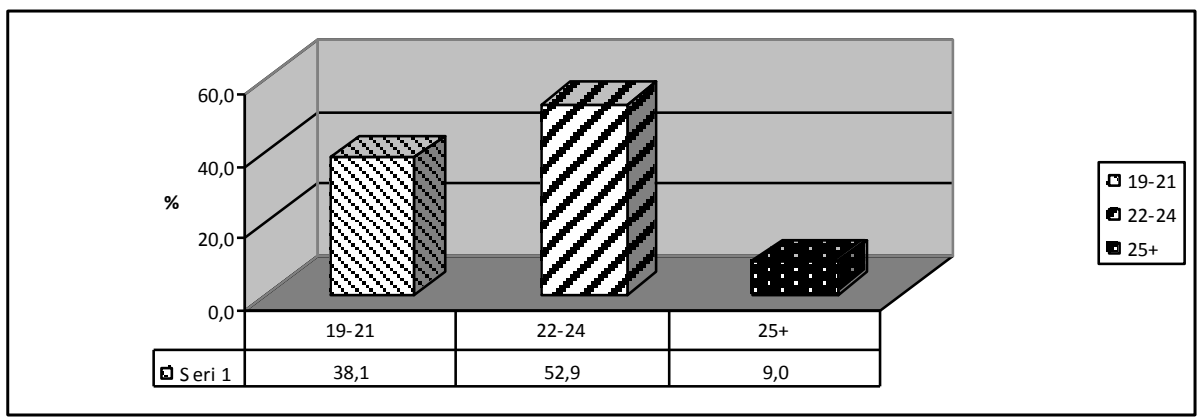

Şekil 2 Okul Öncesinde Drama Dersi Alan Öğrencilerin Yaş Gruplarına Göre Dağıllımları

Şekil 2 incelendiğinde, okul öncesinde drama dersi alan öğrencilerin yaş gruplarına göre dağılımlarını, \% 38.1'ini 19-21 yaş arası olanlar, \%52.9'unu 22-24 yaş arası olanlar, \%9.0'1 25 yaş ve üstü olanlar oluşturmaktadır.

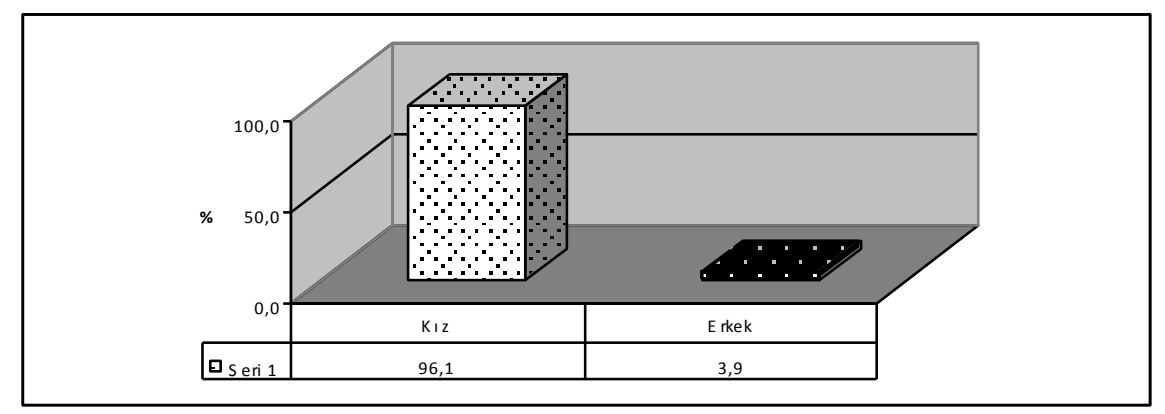

Şekil 3 Okul Öncesinde Drama Dersi Alan Öğrencilerin Cinsiyete Göre Dă̆gllımları 
Şekil 3'e göre okul öncesinde drama dersi alan öğrencilerin cinsiyete göre dağılımları incelendiğinde, \%96.1'i k1z, \% 3.9’u erkektir.

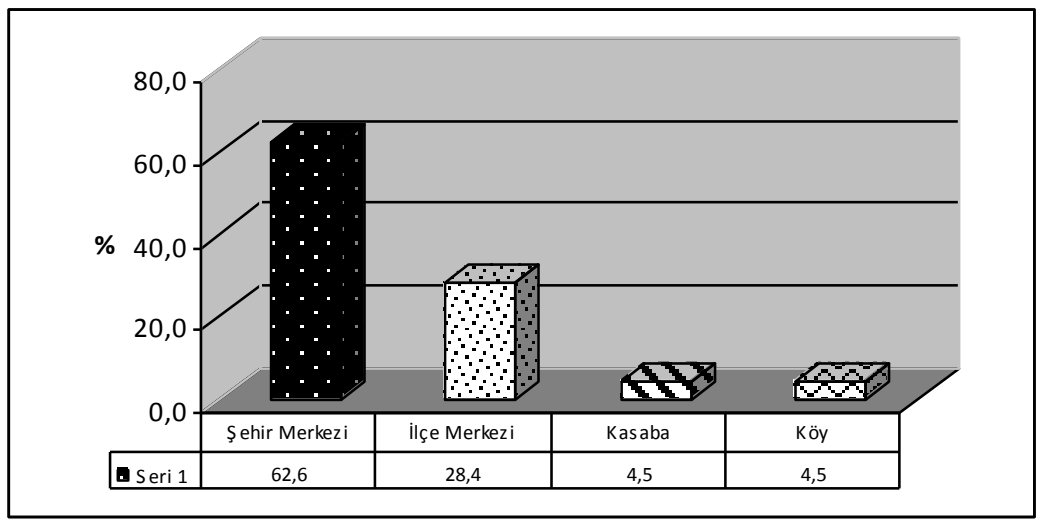

Şekil 4 Okul Öncesinde Drama Dersi Alan Öğrencilerin En Uzun Yaşadıkları Yerleşim Merkezine Göre Dağılımları

Şekil 4 incelendiğinde, öğrencilerin en uzun yaşadıkları yerleşim merkezine göre dağılımlarına bakıldığında, birinci sırayı şehir merkezinde yaşayanlar (\%62.6), ikinci sırayı ilçe merkezinde yaşayanlar (\% 28.4), üçüncü sırayı ise kasaba ve köyde yaşayanlar (\%4.5) oluşturmaktadır.

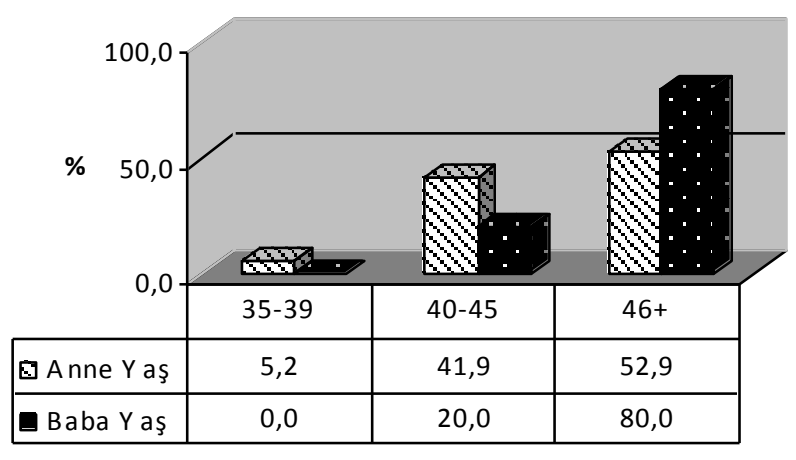

Şekil 5 Okul Öncesinde Drama Dersi Alan Öğrencilerin Anne-Baba Yaş Dağılımları

Şekil 5'te okul öncesinde drama dersi alan öğrencilerin anne-baba yaş dağılımlarına göre, 35-39 yaş arası anneleri olanlar \%5.2'yi, 40-45 yaş arası anneleri olanlar \% 41'i, babaları olanlar \% 20.0'yi, 46 yaş ve üzeri anneleri olanlar \% 52.9'u, babaları olanlar \% 80'i oluşturmaktadır. 


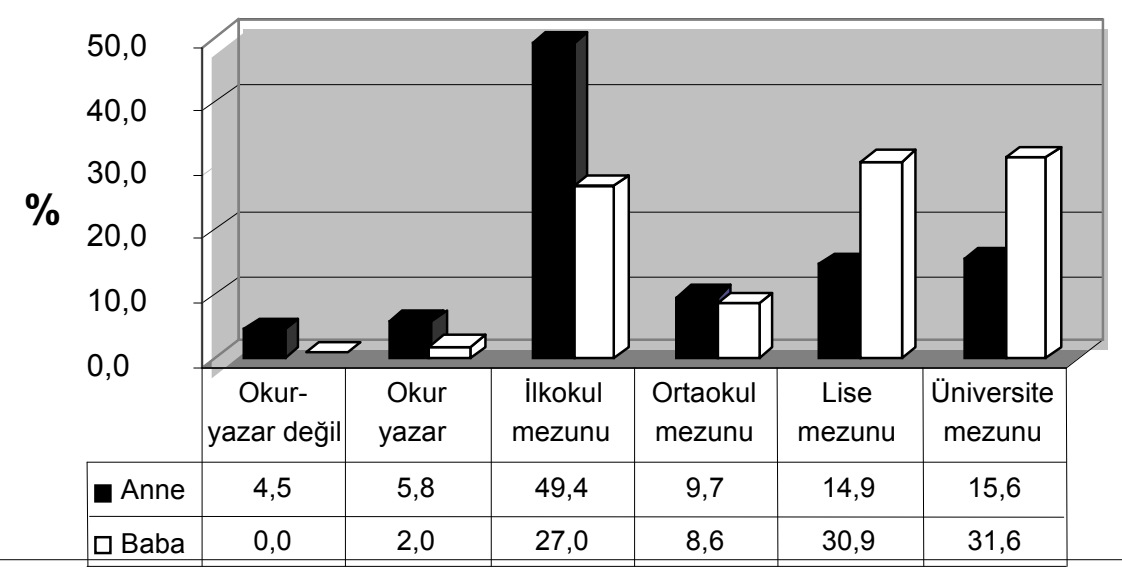

Şekil 6 Okul Öncesinde Drama Dersi Alan Öğrencilerin Anne-Baba Öğrenim Düzeyi Dă̆ıllımları

Şekil 6 incelendiğinde okul öncesinde drama dersi alan öğrencilerin anne öğrenim düzeyine göre, ilk sırayı anneleri ilkokul mezunu olanlar (\%49.4), anneleri üniversite mezunu olanlar (\%15.6) ikinci sırayı, lise mezunu (\%14.9) olanlar üçüncü sırayı, ortaokul mezunu (\%9.7) olanlar dördüncü sırayı, okur- yazar (\%5.8) olanlar beşinci sırayı, okur-yazar olmayanlar (\%4.5) altıncı sırayı almaktadır.

Okul öncesinde drama dersi alan öğrencilerin baba öğrenim düzeyine göre ise, ilk sırada babası üniversite mezunu (\% 31.6) olanlar, ikinci sırada lise mezunu (\% 30.9) olanlar, üçüncü sırada İlkokul mezunu (\% 27.0), dördüncü sırada ortaokul mezunu (\% 8.6) olanlar, beşinci sırada okur yazar (\% 2.0) olanlar yer almaktadır.

Tablo 1 Okul Öncesinde Drama Dersine Katılan Öğrencilerin Aldıkları Puanların Üniversitelere Göre Karşılaştırması

\begin{tabular}{|c|c|c|c|c|c|c|c|c|c|c|}
\hline Üniversiteler & $\mathrm{N}$ & Mean & Median & ss & Min & Max & Sira Ort. & $\begin{array}{l}\text { Kruskall- } \\
\text { Wallis } \\
\text { (Ki-Kare) }\end{array}$ & $\mathrm{sd}$ & $\mathrm{p}$ \\
\hline Ankara Üniversitesi & 35 & 123,06 & 123 & 17,74 & 78 & 150 & 90,44 & & & \\
\hline Hacettepe Üniversitesi & 50 & 113,68 & 114 & 20,36 & 64 & 150 & 67,01 & 5,79 & 3 & 0,122 \\
\hline Gazi Üniversitesi & & & & & & & & & & \\
\hline Eğitim Fakültesi & 32 & 118,44 & 119,5 & 16,01 & 75 & 150 & 80,08 & & & \\
\hline $\begin{array}{l}\text { Gazi Üniversitesi } \\
\text { Mesleki Eğitim } \\
\text { Fakültesi }\end{array}$ & 38 & 118,18 & 120 & 18,65 & 73 & 150 & 79,25 & & & \\
\hline
\end{tabular}


Tablo 1'e göre, okul öncesinde drama dersine katılan öğrencilerin aldıkları puanlarla üniversitelere göre dağılımları arasında anlamlı bir farklılık görülmemektedir ( $>0,05)$. Okul öncesi eğitim öğretmenliği programının ders içeriklerinin Yüksek Öğretim Kurumu tarafından belirlenmektedir. Böylece, tüm üniversitelerin okul öncesi eğitim programlarındaki okul öncesinde drama derslerinin aynı içeriğe sahip olması nedeniyle üniversiteler arasında anlamlı farklılığın olmadığı düşünülebilir.

Tablo 2 Okul Öncesinde Drama Dersine Katılan Öğrencilerin Aldıkları Puanların Cinsiyete Göre Karşılaştırması

\begin{tabular}{|c|c|c|c|c|c|c|c|c|c|}
\hline & & & & & & & Sira & Mann- & \\
\hline Cinsiyet & $\mathrm{N}$ & Mean & Median & SS & Min & Max & Ort. & Whitney U & $\mathrm{p}$ \\
\hline $\mathrm{K} 1 \mathrm{z}$ & 149 & 117,82 & 118 & 18,96 & 64 & 150 & 77,87 & & \\
\hline Erkek & 6 & 119,50 & 120,5 & 9,33 & 106 & 130 & 81,17 & 428 & 0,86 \\
\hline
\end{tabular}

Tablo 2 incelendiğinde, okul öncesinde drama dersine katılan öğrencilerin aldıkları puanlarla cinsiyetler arasında anlamlı bir farklılık görülmemektedir $(\mathrm{p}>0,05)$.

Ünal-Erhan (2000), ilköğretimde hayat bilgisi dersinin drama ile verilmesinin dersin öğrenilmesine ve çocukların benlik kavramlarına etkisini incelediği çalışmasında deney grubundaki kız ve erkek öğrencilerin puan ortalamaları arasındaki farkın önemsiz olduğunu bulmuştur.

Akın ve Önder (2004), altı yaş çocuklarının başkalarının bakış açısını alma yetisi üzerinde eğitici drama programının etkisi üzerine yaptı̆̆ı çalışma sonucunda, cinsiyete göre farklılık olmadı̆̆ını belirtmişlerdir. Bu bulgular araştırma bulgularını destekler niteliktedir.

Tablo 3 Okul Öncesinde Drama Dersine Katılan Öğrencilerin Aldıkları Puanların Yaş Gruplarına Göre Karşılaştırması

\begin{tabular}{lcccccccccc}
\hline & & & & & & & \multicolumn{3}{c}{$\begin{array}{c}\text { Kruskall- } \\
\text { Wallis }\end{array}$} \\
Öğrencinin Yaş1 & N & Mean & Median & ss & Min & Max & Ort. & (Ki-Kare) & sd & p \\
\hline 19-21 yaş arası & 59 & 117,02 & 118 & 16,79 & 73 & 150 & 75,59 & & & \\
22-24 yaş arası & 82 & 118,90 & 118,5 & 19,92 & 64 & 150 & 80,89 & 0,83 & 2 & 0,660 \\
25 yaş ve üstü & 14 & 115,57 & 116 & 19,58 & 78 & 150 & 71,21 & & & \\
\hline
\end{tabular}

Tablo 3'e göre, okul öncesinde drama dersine katılan öğrencilerin aldıkları puanlarla yaş grupları arasında anlamlı bir farklılık görülmemektedir $(\mathrm{p}>0,05)$. Farklı yaş gruplarında yapılan araştırmalarda, yaratıcı drama dersinin tüm yaş gruplarında etkili bir eğitim yöntemi ve disiplin olduğu görülmektedir. Böylece, yaratıcı drama dersi farklı yaş gruplarında yer alan öğrencilerde aynı etkiye sahip olduğu söylenebilir. 
Tablo 4 Okul Öncesinde Drama Dersine Katılan Öğrencilerin Aldıkları Puanların Dramayla ilgili Seminer, Kurs ve Atölyeye Katılma Durumuna Göre Karşılaştırması

\begin{tabular}{lcccccccccc}
\hline & & & & & & & & \multicolumn{3}{c}{ Mann- } \\
$\begin{array}{l}\text { Yaratıc Dramayla İlgili } \\
\text { Seminer, Kurs ve Atölyeye vb. }\end{array}$ & & & & & & & & & \\
Katılma Durumu & & & & & & & Sira & Whitney \\
& Evet & 44 & 119,68 & 123 & 21,65 & 79 & 150 & 83,19 & & \\
Hayır & 111 & 117,17 & 118 & 17,40 & 64 & 150 & 75,94 & 2213,5 & 0,364 \\
\hline
\end{tabular}

Tablo 4'de görüldüğü gibi, okul öncesinde drama dersine katılan öğrencilerin aldıkları puanların dramayla ilgili seminer, kurs ve atölyeye katılma durumuna göre dağılımları arasında anlamlı bir farkl111k görülmemektedir ( $p>0,05)$. Okul öncesinde drama dersi alan öğrencilerin katıldıkları kurs ya da seminer sürelerinin ve içeriğinin birbirinden farklı olduğu düşünüldügünde, farklılık olmamasının doğal olduğu düşünülebilir. Buna göre, öğrencilerin okulda aldıkları okul öncesinde drama dersinden daha fazla etkilendikleri söylenebilir.

Tablo 5 Okul Öncesinde Drama Dersine Katılan Öğrencilerin Aldıkları Puanların Okul Öncesinde Drama Dersinden Başarısız Olma Durumuna Göre Karşılaştırması

\begin{tabular}{|c|c|c|c|c|c|c|c|c|c|}
\hline \multirow{3}{*}{$\begin{array}{l}\text { Okul Öncesinde } \\
\text { Drama Dersinden } \\
\text { Başarısız Olma } \\
\text { durumu }\end{array}$} & & & & & & & \multicolumn{3}{|c|}{ Mann- } \\
\hline & & & & & & & Sira & Whitney & \\
\hline & $\mathrm{N}$ & Mean & Median & SS & Min & Max & Ort. & $\mathrm{U}$ & $\mathrm{p}$ \\
\hline Evet & 11 & 113,73 & 114 & 19,79 & 81 & 143 & 67,45 & & \\
\hline Hayır & 144 & 118,20 & 118 & 18,61 & 64 & 150 & 78,81 & 676 & 0,418 \\
\hline
\end{tabular}

Tablo 5 incelendiğinde, okul öncesinde drama dersine katılan öğrencilerin aldıkları puanlarla okul öncesinde drama dersinden başarısız olma durumları arasında anlamlı bir farklılık görülmemektedir $(\mathrm{p}>0,05)$.

Can-Yaşar ve Ömeroğlu (2005), drama dersi alan kız meslek lisesi son sınıf öğrencilerinin drama dersine ilişkin görüşlerinin inceledikleri araştırmada, öğrencilerin yarısından çoğunun drama dersini her zaman meslekleri için çok önemli gördüklerini bulmuşlardır. Buna göre, öğrenciler dersten başarısız bile olsalar dersi önemli gördükleri düşünülebilir. 
Tablo 6 Okul Öncesinde Drama Dersine Katılan Öğrencilerin Aldıkları Puanların Seçmeli Ders Olarak İkinci Kez Alma Durumuna Göre Karşılaştırması

\begin{tabular}{|c|c|c|c|c|c|c|c|c|c|}
\hline $\begin{array}{l}\text { Okul Öncesinde Dramayı } \\
\text { Seçmeli Ders Olarak İkinci Kez } \\
\text { Alma Durumu }\end{array}$ & $\mathrm{N}$ & Mean & Median & ss & Min & Max & $\begin{array}{l}\text { Sira } \\
\text { Ort. }\end{array}$ & $\begin{array}{c}\text { Mann- } \\
\text { Whitney } \\
\text { U }\end{array}$ & $\mathrm{p}$ \\
\hline Evet & 12 & 130,25 & 133,5 & 17,49 & 104 & 150 & 106,17 & & \\
\hline Hayır & 143 & 116,85 & 118 & 18,44 & 64 & 150 & 75,64 & 520 & $0,023^{*}$ \\
\hline
\end{tabular}

Tablo 6'ya göre okul öncesinde drama dersi puanlarıyla seçmeli ders olarak ikinci kez okul öncesinde drama dersini alma durumları arasında anlamlı bir farklılık görülmektedir $(\mathrm{p}<0,05)$. İkinci kez okul öncesinde drama dersini alanlarda puanlar daha yüksek olduğu görülmektedir. Buna göre, okul öncesinde drama dersine ikinci kez katılan öğrencilere daha fazla katkı sağladığı söylenebilir. Böylece, öğrencilerin okul öncesinde dramaya daha fazla süre katılması onların farkındalık düzeyini arttırdığı ve kendilerine sağladığ gelişimin daha fazla farkında oldukları düşünülebilir.

Noble, Ergan ve McDowell (1977), yaratıcı dramanın yoksul bölgelerdeki yedi yaşındaki çocukların benlik kavramlarının değiştirilmesi üzerine yaptıkları araştırma sonuçları, yaratıcı dramaya katılan çocukların test sonucunda kendilerini çizmeleri istendiğinde daha eksiksiz ve kendi özelliklerine daha uygun resim çizdiklerini göstermektedir.

Erdoğan (2006) ilköğretim 8. sınıf (14-15 yaş) öğrencilerinin öz kavram düzeylerine yaratıcı dramanın etkisini incelediği araştırmasında, yaratıcı dramanın öğrencilerin öz kavram düzeylerinde olumlu yönde artışa neden olduğu görülmüştür.

Yeğen (2004), dramanın mesleki beceri ve kişilik özelliklerini desteklediğini belirtmektedir.

Yapılan araştırma sonuçlarına göre, eğitim -öğretimin tüm kademelerinde alınan yaratıcı drama dersi öğrencilerin kişilik özellikleri, benlik kavramları, öz kavram düzeylerinde olumlu yönde desteklenmektedir. Eğitim programlarında yaratıcı drama dersine katılma süresi ne kadar artarsa, öğrencinin gelişimine katkısının da arttığı görülmektedir. 


\begin{tabular}{|c|c|c|c|c|c|c|c|c|c|c|}
\hline \multirow{4}{*}{$\begin{array}{l}\text { Okul Öncesinde } \\
\text { Drama Dersini } \\
\text { Aldığı Eğitim } \\
\text { Ortamı }\end{array}$} & & & & & & \multicolumn{5}{|c|}{ Kruskall- } \\
\hline & & & & & & & & Wallis & & \\
\hline & & & & & & & Sira & (Ki- & & \\
\hline & $\mathrm{N}$ & Mean & Median & ss & Min. & Max. & Ort. & Kare) & $\mathrm{Sd}$ & $\mathrm{p}$ \\
\hline Sinif & 42 & 120,02 & 117,5 & 16,17 & 87 & 150 & 80,37 & & & \\
\hline Drama Atölyesi & 86 & 117,05 & 118 & 19,13 & 64 & 150 & 75,73 & 0,328 & 2 & 0,849 \\
\hline Salon & 26 & 117,73 & 120 & 21,35 & 75 & 150 & 78,71 & & & \\
\hline
\end{tabular}

Tablo 7'ye bakıldığında, okul öncesinde drama dersine katılan öğrencilerin aldıkları puanlarla dersi aldıkları eğitim ortamları arasında anlamlı farklılık görülmemektedir ( $p>0,05)$. Araştırmaya alınan üniversitelerde okul öncesinde drama derslerinin çoğunluğunun drama atölyelerinde yapıldığ1 görülmektedir. Ancak, analiz sonuçlarına göre okul öncesinde drama dersinin drama atölyesinde, sınıf ya da salonda alınmasının anlamlı bir fark yaratmamasının nedeni olarak okul öncesinde drama dersinin içeriğinin, eğitimcinin tutumunun ve anlatım tekniklerinin vb. etkenlerin de etkisini düşündürebilir.

Tablo 8 Okul Öncesinde Drama Dersi Alan Öğrencilerin Dersin Kendilerine Olan Katkılarına İlişkin Görüşlerinin Dağlımı

\begin{tabular}{|c|c|c|c|c|c|c|c|c|c|c|}
\hline & \multicolumn{2}{|c|}{ 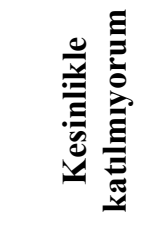 } & \multicolumn{2}{|r|}{ 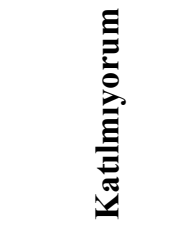 } & \multicolumn{2}{|c|}{ 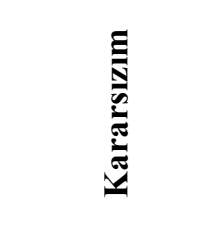 } & \multicolumn{2}{|r|}{ 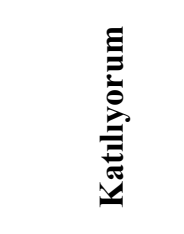 } & \multirow[t]{2}{*}{ ڤ્气 } & \multirow{2}{*}{ 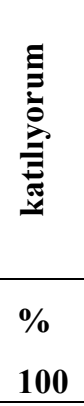 } \\
\hline & $\begin{array}{c}n \\
155 \\
\end{array}$ & $\begin{array}{l}\% \\
100 \\
\end{array}$ & $\begin{array}{c}n \\
155 \\
\end{array}$ & $\begin{array}{l}\% \\
100 \\
\end{array}$ & $\begin{array}{c}n \\
155 \\
\end{array}$ & $\begin{array}{l}\% \\
100 \\
\end{array}$ & $\begin{array}{c}n \\
155 \\
\end{array}$ & $\begin{array}{l}\% \\
100 \\
\end{array}$ & & \\
\hline $\begin{array}{l}\text { 1. Yaratıcı drama etkinlikleri } \\
\text { kendimi sözel olarak daha iyi } \\
\text { ifade edebilmemi sağladı. }\end{array}$ & & & 15 & 9,7 & 24 & 15,5 & 70 & 45,2 & 46 & 29,7 \\
\hline $\begin{array}{l}\text { 2. Yaratıcı drama etkinlikleri } \\
\text { grup içinde rahatlıkla çalışma } \\
\text { fırsatı yarattı. }\end{array}$ & 1 & 0,6 & 9 & 5,8 & 14 & 9,0 & 78 & 50,3 & 53 & 34,2 \\
\hline 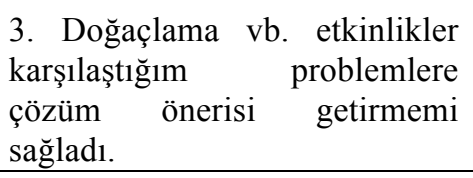 & 2 & 1,3 & 11 & 7,1 & 23 & 14,8 & 78 & 50,3 & 41 & 26,5 \\
\hline 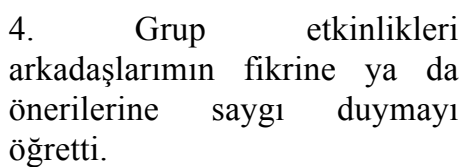 & 2 & 1,3 & 7 & 4,5 & 20 & 12,9 & 74 & 47,7 & 52 & 33,5 \\
\hline
\end{tabular}




\begin{tabular}{|c|c|c|c|c|c|c|c|c|c|c|}
\hline $\begin{array}{l}\text { 5. Grup etkinlikleri görüşlerimi } \\
\text { ortaya koymamı sağladı. }\end{array}$ & - & - & 10 & 6,5 & 14 & 9,0 & 79 & 51,0 & 52 & 33,5 \\
\hline $\begin{array}{ll}\text { 6. Yaratıcı drama eğitimi } \\
\text { yaratıcı ürünler } & \text { ortaya } \\
\text { çıkartmama firsat verdi. } & \end{array}$ & 1 & 0,6 & 10 & 6,5 & 25 & 16,1 & 68 & 43,9 & 51 & 32,9 \\
\hline $\begin{array}{l}\text { 7. Yaratıcı drama eğitimi } \\
\text { kendimi ve duygularımı ifade } \\
\text { etmemi sağladı. }\end{array}$ & - & - & 10 & 6,5 & 21 & 13,5 & 74 & 47,7 & 50 & 32,3 \\
\hline $\begin{array}{l}\text { 8. Yaratıcı drama eğitimi güçlü } \\
\text { ve zayıf yönlerimi fark etmemi } \\
\text { sağlad. }\end{array}$ & - & - & 20 & 12,9 & 27 & 17,4 & 61 & 39,4 & 47 & 30,3 \\
\hline $\begin{array}{l}\text { 9. Yaratıcı drama etkinliklerinin } \\
\text { sonunda kendime güvenim arttı. }\end{array}$ & 2 & 1,3 & 17 & 11,0 & 31 & 20,0 & 57 & 36,8 & 48 & 31,0 \\
\hline $\begin{array}{l}\text { 10. Yaratıcı drama eğitimi grup } \\
\text { arkadaşlarıma güvenimi arttırdı. }\end{array}$ & - & - & 24 & 15,5 & 44 & 28,4 & 57 & 36,8 & 30 & 19,4 \\
\hline $\begin{array}{l}\text { 11. Yaratıcı drama uygulamaları } \\
\text { sırasında arkadaşlarımla } \\
\text { paylaşımlarım arttı. }\end{array}$ & 1 & 0,6 & 8 & 5,2 & 13 & 8,4 & 70 & 45,2 & 63 & 40,6 \\
\hline $\begin{array}{l}\text { 12. Yaratıcı drama etkinlikleri } \\
\text { sirasında sorumluluk duygum } \\
\text { gelişti. }\end{array}$ & 2 & 1,3 & 17 & 11,0 & 27 & 17,4 & 70 & 45,2 & 39 & 25,2 \\
\hline $\begin{array}{l}\text { 13. Bazı etkinliklerde liderlik } \\
\text { yapma firsatı sağladı. }\end{array}$ & 4 & 2,6 & 19 & 12,3 & 19 & 12,3 & 71 & 45,8 & 42 & 27,1 \\
\hline 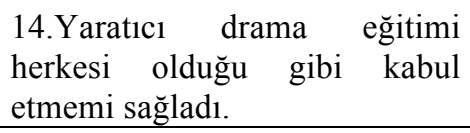 & 3 & 1,9 & 19 & 12,3 & 39 & 25,2 & 54 & 34,8 & 40 & 25,8 \\
\hline $\begin{array}{l}\text { 15.Yaratıcı drama uygulamaları } \\
\text { empati (başkalarını anlama) } \\
\text { becerimi arttırdı. }\end{array}$ & 2 & 1,3 & 10 & 6,5 & 23 & 14,8 & 77 & 49,7 & 43 & 27,7 \\
\hline $\begin{array}{l}\text { 16.Yaratıcı drama eğitimi } \\
\text { yaşamdaki bazı ayrıntılara } \\
\text { dikkat etmemi sağladı. }\end{array}$ & 1 & 0,6 & 7 & 4,5 & 20 & 12,9 & 81 & 52,3 & 46 & 29,7 \\
\hline $\begin{array}{l}\text { 17. Yaratıc1 drama eğitimi } \\
\text { karşılaştığım sorunlara karş1 } \\
\text { daha hoşgörülü yaklaşmamı } \\
\text { sağlad. }\end{array}$ & 1 & 0,6 & 16 & 10,3 & 35 & 22,6 & 67 & 43,2 & 36 & 23,2 \\
\hline $\begin{array}{lcr}\text { 18. Yaratıcı drama eğitimi } \\
\text { toplumdaki } & \text { kişilere } & \text { daha } \\
\text { duyarlı hale gelmemi sağladı. }\end{array}$ & & & 18 & 11,6 & 33 & 21,3 & 72 & 46,5 & 32 & 20,6 \\
\hline $\begin{array}{l}\text { 19. Yaratıc1 drama eğitimi } \\
\text { beden dilimi daha iyi } \\
\text { kullanmamı sağladı. }\end{array}$ & 1 & 0,6 & 8 & 5,2 & 19 & 12,3 & 73 & 47,1 & 54 & 34,8 \\
\hline $\begin{array}{l}\text { 20. Yaratıcı drama duygularım } \\
\text { daha kolay kontrol etmemi } \\
\text { sağlad. }\end{array}$ & 0 & 0 & 20 & 12,9 & 37 & 23,9 & 58 & 37,4 & 40 & 25,8 \\
\hline
\end{tabular}




\begin{tabular}{|l|c|c|c|c|c|c|c|c|c|c|}
\hline $\begin{array}{l}\text { 21. Yaratıcı drama eğitimi } \\
\text { bedenimi daha estetik } \\
\text { kullanmamı sağladı. }\end{array}$ & 1 & 0,6 & 14 & 9,0 & 41 & 26,5 & 65 & 41,9 & 34 & 21,9 \\
\hline $\begin{array}{l}\text { 22. Yaratıc drama eğitimi } \\
\text { etrafımdaki olaylara farklı bakış } \\
\text { açılarıla bakmayı ögretti. }\end{array}$ & 1 & 0,6 & 13 & 8,4 & 23 & 14,8 & 70 & 45,2 & 48 & 31,0 \\
\hline $\begin{array}{l}\text { 23. Yaratıcı drama duygu ve } \\
\text { düşüncelerimi farklı şekillerde } \\
\text { ifade etmemi sağladı. }\end{array}$ & 1 & 0,6 & 12 & 7,7 & 21 & 13,5 & 81 & 52,3 & 40 & 25,8 \\
\hline $\begin{array}{l}\text { 24. Yaratıcı drama eğitimi } \\
\text { etrafımdaki eşya ve nesnelere } \\
\text { daha detaylı bakmayı öğrtti. }\end{array}$ & - & - & 14 & 9,0 & 19 & 12,3 & 69 & 44,5 & 53 & 34,2 \\
\hline $\begin{array}{l}\text { 25. Yaratıcı drama eğitimi } \\
\text { olaylara eleştirisel bir bakış } \\
\text { açısılla bakmamı sağladı. }\end{array}$ & - & - & 19 & 12,3 & 25 & 16,1 & 70 & 45,2 & 41 & 26,5 \\
\hline $\begin{array}{l}\text { 26. Yaratıcı drama eğitimi } \\
\text { değişikliklere daha açı hale } \\
\text { gelmemi sağladı. }\end{array}$ & 1 & 0,6 & 15 & 9,7 & 23 & 14,8 & 69 & 44,5 & 47 & 30,3 \\
\hline $\begin{array}{l}\text { 27. Yaratıcı drama eğitimi } \\
\text { kendimi önemli hissetmemi } \\
\text { sağladı. }\end{array}$ & 4 & 2,6 & 24 & 15,5 & 37 & 23,9 & 59 & 38,1 & 31 & 20,0 \\
\hline $\begin{array}{l}\text { 28. Yaratıcı drama eğitimi } \\
\text { olaylara neşeli ve mizahi } \\
\text { yanlarıyla bakmamı sağlad. }\end{array}$ & 2 & 1,3 & 12 & 7,7 & 21 & 13,5 & 60 & 38,7 & 60 & 38,7 \\
\hline $\begin{array}{l}\text { 29. Yaratıcı drama eğitimi } \\
\text { olaylar arasında daha kolay } \\
\text { bağlantılar kurmama neden } \\
\text { oldu. }\end{array}$ & 2 & 1,3 & 9 & 5,8 & 27 & 17,4 & 77 & 49,7 & 40 & 25,8 \\
\hline $\begin{array}{l}\text { 30. Yaratıcı drama eğitimi } \\
\text { alanımla ilgili yeni bilgiler } \\
\text { kazanmamı sağladı. }\end{array}$ & 1 & 0,6 & 6 & 3,9 & 13 & 8,4 & 70 & 45,2 & 65 & 41,9 \\
\hline
\end{tabular}

Tablo 8'de, okul öncesinde drama dersi alan öğrencilerin dersin kendilerine olan katkılarına ilişkin görüşleri yer almaktadır. Formda 1- 30 arası olan sorulara bakıldığında öğretmen adaylarının yarıdan fazlasının "Katılıyorum" şeklinde cevap verdikleri görülmektedir. Tablo 1 incelendiğinde, yaratıcı drama dersi alan öğrencilerin kendilerine sağladığı katkıyla ilgili “Tamamen Katılıyorum” şeklinde verdikleri cevaplarda en yüksek değerler \% 41.9 yaratıcı drama eğitimi alanımla ilgili yeni bilgiler kazanmamı sağladı, \% 40.6 yaratıcı drama uygulamaları sırasında arkadaşlarımla paylaşımlarım arttı şeklindedir. "Katılıyorum"a en yüksek verdikleri yanıtlar \%52.3 yaratıcı drama eğitimi yaşamdaki bazı ayrıntılara dikkat etmemi sağladı ve yaratıcı drama duygu ve düşüncelerimi farklı şekillerde ifade etmemi sağladı, \%51 grup etkinlikleri görüşlerimi ortaya koymamı sağladı, \%50.3 doğaçlama vb. etkinlikler karşılaştı̆̆ım problemlere çözüm önerisi getirmemi sağladı olarak sıralanabilir. "Kesinlikle 
Katılmıyorum" a en yüksek \%2,6 ile bazı etkinliklerde liderlik yapma firsatı sağladı ve yaratıcı drama eğitimi kendimi önemli hissetmemi sağladı şeklindedir. "Katılmıyorum" a ise en yüksek \%15,5 ile yaratıcı drama eğitimi kendimi önemli hissetmemi sağladı ve yaratıcı drama eğitimi grup arkadaşlarıma güvenimi arttırdı şeklindeki cevaplardır. Böylece, yaratıcı drama dersi alan öğrencilerin forma verdikleri cevaplara göre yarıdan fazlasının okul öncesinde drama eğitiminin kendilerine bir çok alanda katkı sağladı ̆̆ını belirtmişlerdir.

Dikici ve diğ. (2003) Yaratıcı drama dersi alan üniversite öğrencilerin problem çözme becerilerini incelediği araştırmalarında, yaratıcı drama eğitiminin problem çözme davranışları üzerinde anlamlı düzeyde etkisi olduğu bulunmuştur.

Güven-Metin (1999), dramanın 5-6 yaş çocuklarının sosyal-duygusal gelişimini etkisini incelediği araştırmasında, çocukların soysal -duygusal gelişimleri açısından anlamlı farklılık ortaya çıktığını bulmuştur.

Kara ve Çam (2007), yaratıcı drama yönteminin bazı sosyal becerilerin kazandırılmasına etkisi ile ilgili araştırmalarında, grupla bir işi yapma ve yürütme becerilerinin kazandırılması konusunda yaratıcı drama yönteminin etkili olduğunu belirtmişlerdir.

Bu bulgularda, kişiye olan bir çok katkısıyla ilgili sonucu destekler niteliktedir.

Tablo 9 Okul Öncesinde Drama Dersi Alan Öğrencilerin Dersin Kendilerine Olan Katkılarına İlişkin Görüşlerine Yönelik Medyan, Minimum, Maximum Değerleri.

\begin{tabular}{|c|c|c|c|c|c|c|}
\hline Okul Öncesinde Drama Dersi Alan & $\mathrm{N}$ & Mean & Medyan & ss & Minimum & Maximum \\
\hline $\begin{array}{l}\text { Öğrencilerin Dersin Kendilerine } \\
\text { Olan Katkılarına İlişkin Toplam }\end{array}$ & & & & & & \\
\hline Puanları & 155 & 117,9 & 118 & 18,7 & 64 & 150 \\
\hline
\end{tabular}

Tablo 9'da görüldüğü gibi, öğrencilerin okul öncesinde drama dersinin kendilerine olan katkılarına ilişkin görüşlerinin minimum değerinin 64, maximum değerinin 150 arasında değiştiği, medyan değerinin ise 118 olduğu görülmektedir. Bu da öğrencilerin okul öncesinde drama dersinin kendilerine olan katkılarına ilişkin görüşlerinin olumlu yönde olduğunu göstermektedir.

\section{Sonuç ve Öneriler}

Araştırma sonuçlarına göre, okul öncesi eğitimi öğretmenlik programındaki üniversite öğrencilerinin aldıkları puanla, öğrencilerin devam ettikleri üniversiteleri, cinsiyetleri, yaşları, yaratıcı drama kurslarına katılma durumları, okul öncesinde drama dersinden başarısız olma durumları ve okul öncesi drama 
eğitimi aldıkları ortamlar arasında anlamlı bir farklılık görülmemektedir ( $p>0,05)$. Ancak, okul öncesinde drama dersini ikinci kez seçmeli olarak alanlarla almayanlar arasında, alanlar lehine anlamlı bir farklılık görülmektedir $(\mathrm{p}<0,05)$. Ayrıca, okul öncesinde drama dersi alan öğrencilerin forma verdikleri cevaplara göre yarıdan fazlasının okul öncesinde drama eğitiminin kendilerine bir çok alanda katkı sağladığını belirtmişlerdir. Öğrencilerin okul öncesinde drama dersinin kendilerine olan katkılarına ilişkin görüşlerinin olumlu yönde olduğu bulunmuştur.

Okul öncesi öğretmen adaylarının farklı alt yapılardan geldikleri düşünülürse, üniversitede aldıkları eğitimin önemi ortaya çıkmaktadır. Öğrencilerin, yaparak yaşayarak öğrenme fırsatı buldukları yaratıcı drama mesleklerini sevmelerini, kişisel gelişimlerine katkı sağlamalarını ve geleceğin yetişkinleri olacak çocukların duygu ve düşüncelerini daha kolay anlamalarını sağlayacaktır. Bu nedenle, okul öncesinde drama derslerinin drama alanında yeterli ve uzman kişiler tarafından verilmesi önem taşımaktadır.

Okul öncesinde dramanın kendi gelişimlerine katkısını kavrayan öğretmen adaylarının ileride, eğitim programlarında okul öncesinde drama eğitimine yer vermesi çocukların tüm gelişimlerini destekleyerek bilgiye daha kolay ulaşmalarını sağlayacaktır. Ayrıca, çocukların problem çözme, iş birliği sağlama, kendini ifade etme, sorumlulukları paylaşma gibi becerilerine de katkıda bulunacaktır.

$\mathrm{Bu}$ sonuçlar doğrultusunda, aşağıda araştırmaya yönelik özel ve konuyla ilgili genel öneriler verilebilir:

- Üniversitelerdeki eğitim fakültelerinde okul öncesinde drama dersinin, alanında yeterli bilgi ve donanıma sahip eğitimciler tarafından yürütülmesi öğrencilerin duygu ve düşüncelerini farklı şekillerde ifade etmelerine, grup etkinliklerinde görüşlerini ortaya koymalarına, karşılaştığı problemlere çözüm önerisi getirmelerine katkı sağlayacaktır.

- Okul öncesi eğitim programlarında drama dersinin bir yarıyıl olması yerine, iki yarıyıllık bir ders olarak yürütülmesi öğrencilerin derse karşı tutumlarını değiştirmek için daha yeterli olacaktır.

- Yaratıcı drama dersinin zorunlu ders olarak yer almasının yanı sıra, isteyen öğrencilerin seçmeli ders olarak alabilmesi için programda yer alması sağlanabilir.

- Üniversitelerde belirli aralıklarla öğrencilerin ilgilerini çekmek ve dramayla tanışmalarını sağlamak için konulu yaratıcı drama atölyeleri yürütülebilir.

- Yaratıcı drama dersinin üniversitelerde okul öncesi eğitimi öğretmenliği programının dışında tüm öğretmenlik programlarında yer alması sağlanabilir. 
- Öğretmen adayları, yaratıcı dramanın önemi ve kullanımı konularında seminer, panel, konferans, kurs ve atölyeye vb. etkinliklere yönlendirilebilirler.

- Üniversitelerde yaratıcı drama araştırma ve uygulama merkezi kurularak bu alanda çalışmalar desteklenebilir.

- Üniversitelerde yaratıcı drama topluluğu oluşturularak daha çok öğrenciye ulaşıllabilir.

\section{Kaynaklar}

Adıgüzel, H.Ö. (2006a). Yaşantılara dayalı öğrenme, yaratıcı drama ve süreçsel drama ilişkileri. Yaratıcı Drama Dergisi, 1(1), 31-36.

Adıgüzel, H.Ö. (2006b). Yaratıcı drama derslerine (Okul Öncesinde Drama ve İlköğretimde Drama) ilişkin tutum ölçeği geliştirilmesi. Yaratıcı Drama Dergisi, 1(2), 7-11.

Akoğuz, M. (2002). Iletiş̧im becerilerinin geliştirilmesinde yaratıcı dramanın etkisi. Yayınlanmamış Yüksek Lisans Tezi, Ankara: Ankara Üniversitesi.

Akın, Y. ve Önder, A. (2004). Altı yaş çocuklarının başkalarının bakış açısını alma yetisi üzerinde eğitici drama programının ve aile tutumlarının etkisi. OMEP 2003 Dünya Konsey Toplantısı ve Konferansi, Kuşadası, 5-11 Ekim.

Can Yaşar, M., ve Ömeroğlu, E. (2005). Drama dersi alan kız meslek lisesi son sınıf öğrencilerinin drama dersine ilişkin görüşlerinin incelenmesi. Eğitimde Yeni Yönelimler II Ĕğitimde Oyun Sетровуити. Özel Tevfik Fikret Okulları, Ankara, 14 Mayıs.

Dikici, H., Gündoğdu,R ve Koç,M.(2003). Yaratıcı dramanın problem çözme becerilerine etkisi. VII. Ulusal Psikolojik Danışma ve Rehberlik Kongresi, İnönü Üniversitesi, Malatya, 9-11 Temmuz.

Erdoğan, G. (2006). İlköğretim 8. sinlf (14-15 yaş) ögrencilerinin depresif belirti ve öz kavram düzeylerine yaratıcı drama çalışmalarının etkisinin incelenmesi. Yayınlanmamış Yüksek Lisans Tezi, Ankara: Gazi Üniversitesi.

Erkan, H. (2005). Altı yaş grubu çocukların yaratıcılıklarına drama ve rahatlama çalışmalarının etkisi. Yayınlanmamış Yüksek Lisans Tezi, Ankara: Gazi Üniversitesi.

Freeman,G., Sullivan,K. ve Fulton,C.R. (2003). Effects of creative drama on self-concept, and problem behavior. Journal of Educational Research,96(131).

Genç, N. (2004). Drama eğitiminin üniversite öğrencilerinin öğretmen, arkadaş, eğitim ve okula yönelim tutumlarına etkisi. Çăgdaş Eğitim, 314, 30-38.

Güven Metin, G. (1999). Dramanın 5-6 yaş çocuklarının sosyal-duygusal gelişimlerine etkisinin incelenmesi. Yayınlanmamış Yüksek Lisans Tezi, İstanbul: Marmara Üniversitesi.

Kandır, A. (2003). Yaratıcı Dramanın Okul Öncesi Eğitim Programındaki Yeri ve Hedefleri.(Ed.) Okul Öncesi Eğitimde Drama.(1. Baskl). Ankara: Kök Yayıncılık,

Kara, Y. ve Çam, F. (2007). Yaratıcı drama yönteminin bazı sosyal becerilerin kazandırılmasına etkisi. Hacettepe Üniversitesi Ĕgitim Fakültesi Dergisi, 32, 145-155.

Köksal Akyol, A. ve Çiftçibaşı (2004). Okul Öncesi Eğitimi Öğretmenlerinin Yetişmesinde Dramanın Önemi ve "Okul Öncesi Eğitimde Drama” Dersini Veren Öğretim Elamanında (Liderde) Olması Gereken Özellikler. N. Aslan (Ed.). Drama Liderliği. Ankara: Oluşum Yayınları, 
Noble, G., Ergan, P., McDowell, S. (1977). Changing the self-concepts of seven-year-old deprived urban children by creative drama or videofeedback. Social Behavior and Personality, 5(1), 55-64.

Okvuran, A. (1993). Yaratıcı drama eğitiminin empatik beceri ve empatik eğilim düzeylerine etkisi. Yayınlanmamış Yüksek Lisans Tezi, Ankara: Ankara Üniversitesi.

San, İ. (2002). Eğitimde Yaratıı Drama. H.Ö. Adıgüzel (Ed.) Yaratıcı Drama. (1. Baskı) Ankara: Naturel Yayınc1lık,

Uysal, F.N. (1996). Anaokuluna giden 5-6 yaş grubu çocuklarda yaratıcı drama çalışmalarının sosyal gelişim alanına olan etkisinin incelenmesi. Yayınlanmamış Yüksek Lisans Tezi, Ankara: Ankara Üniversitesi.

Ünal-Erhan, T. (2000). Illkögretimde hayat bilgisi dersinin drama ile verilmesinin dersin öğrenilmesine ve çocukların benlik kavramlarına etkisinin incelenmesi. Yayınlanmamış Bilim Uzmanlığı Tezi, Ankara: Hacettepe Üniversitesi.

Yeğen, G. (2004). Eğitim Fakültelerindeki Yaratıcı Drama Eğitimi, Türkiye'de Drama Liderleri Buluşmast ve 6. Ulusal Drama Semineri Kitabı, Ankara: Drama Liderliği Oluşum Yayınları,

Yayla, Ş ve Ömeroğlu, E. (2005). Yaratıcı drama uygulamalarının 5-6 yaş çocuğunun sosyal-duygusal gelişimine etkisi. Ĕgitimde Yeni Yönelimler II Eğitimde Oyun Sempozyumu. Özel Tevfik Fikret Okulları. Ankara, 14 Mayıs. 


\title{
Summary
}

\section{The Analysis in Contribution of Drama Lessons to University Students at Preschool Education According to Some Variables}

\author{
Şehnaz CEYLAN. Esra ÖMEROĞLU
}

Gazi University

\begin{abstract}
Introduction
The role of teacher within current educational approaches is; making students attain new information, as well as discovering their interests, wishes and talents, making them be able to relate reason and result, improving their ability to solve problems, making them be a good observer and express their feelings in various ways, and also helping them to attain a creative and aesthetic perspective by allowing them to work in a group. Teacher can reach these educational objectives through various methods of teaching and education. One of these teaching methods is creative drama. Learning targeting cognitive, emotional and motional fields depending on the lives can be realized through the education of creative drama (Kandır, 2003: s.22; Genç, 2004: s.31).

It has been stressed in the studies conducted that the education of creative drama help students feel self esteem and confide others, improve their ability to feel empathy to communicate and solve problems, improve in terms of social - emotional ways, communicate their surrounding positively and improve their creativity at every stage of teaching (Akoğuz, 2002; Erkan, 2005; Dikici, Gündoğdu ve Koç, 2003; Kara ve Çam, 2007; Metin, 1999; Okvuran, 1993; Yayla ve Ömeroğlu, 2005). Early childhood period is particularly important in attaining these values.

In order to make the students attain these values, the teacher of preschool education should have them as well. The course of drama has been studied as a compulsory course at the programs of "Preschool Education" of the faculties of education from 1997 onwards (Adigüzel, 2006, p. 8). The course of drama at preschool education takes place at the sixth semester of the program four hours a week, as theoretical and practical one. Drama course at preschool education contains the description of drama, differences and similarities between the types of drama, its history, the importance and benefits of game and drama in terms of child development and education, the technique of drama, drama types, locating drama
\end{abstract}

-Res. Assist., Gazi University, Vocational Educational Faculty, PreschoolEducation Division,E-mail: sehnazc@gmail.com

*** Prof. Dr., Gazi University, Vocational Educational Faculty, Preschool Education Division, E-mail: esra.omeroglu@gmail.com 
activities into daily and weekly schedules. Therefore, the course of drama at preschool education aims at making the students studying at the preschool education programs of the universities attain related knowledge and talents. The pre-school teachers aware of the importance of drama at preschool education will help to make the students attain such talents as solving problems, empathy and social ones etc. through creative drama by improving their own abilities after the graduation.

In this sense, the aim of the current study is to examine whether the course of drama contributes to university students attending to the teaching program of preschool education in terms of the variables of the university they attend, their genders, ages, the status of participating the course of creative drama, the status of the failure at the course of creative drama and environment where they take the course of creative drama.

\section{Method}

\section{Sample}

This study was carried out at Gazi University, Faculty of Education and Faculty of Vocational Education, Ankara University, Faculty of Education and Hacettepe University, Faculty of Education, which all train teachers for preschool education. 155 fourth grade students attending to the Teaching Program of Preschool Education of these four faculties and taking the course of drama at preschool education consisted the sampling of the current study.

\section{Data Collection Instrument}

"Personal Information Form" was used to determine such demographic features as the ages of students, their genders, the faculties they attend, the location where they lived the longest, the age of their parents and their level of education and "The Evaluation Form for the Contribution of the Course of Creative Drama to Students" prepared by the researchers in order to evaluate the contribution of the course of drama to the students were used to collect data. The latter one consisted of 30 items in total. Students responded the questions in the form by indicating 5 level styles as "Strongly agree", "Agree", "Undecided", "Disagree" and "Strongly Disagree". The scoring was sorted out starting from "Strongly Agree" varying from 5 to 1 . All the items prepared in the form were considered as positive items. The highest score a student gets in the form is 150 while the lowest one is 30 . If students respond all the items in the form as "Strongly Agree", they will get 150 points. So, the scores of the students vary.

\section{Procedure}

The Evaluation Form for the Contribution of the Course of Creative Drama to Students at preschool education was applied to the students taking the course of drama at preschool education at the teaching 
programs of Gazi University, Faculty of Education and Faculty of Vocational Education, Ankara University, Faculty of Education and Hacettepe University, Faculty of Education by the researches in the classroom environment at the educational term of $2006-2007$.

The data gathered from the groups included in the sampling was analyzed using the statistical program of S.P.S.S. The data obtained was analyzed depending on independent variables and "Kruskall - Wallis (Chi Square)" and "Mann Whitney U - Test" were used in these analyses. Percentage values and median, minimum, maximum values of the ideas of the students taking the course of creative drama over its contribution to themselves were given.

\section{Conclusion and Suggestions}

Depending on the results of the study, it is clear that there was no significant difference between the scores of the university students attending to the teaching program of preschool education and the universities they attend, their genders, ages, the status of participating in the course of creative drama, the status of failure at the course of drama at preschool education period and the environments where they take drama at preschool education $(p>0.05)$. However, there was a significant difference between the ones taking the course of drama for the second time as a selective one and those not taking it, in favor of the ones taking it $(\mathrm{p}<0.05)$. In addition, it was found that the ideas of the students over the contribution of the course of creative drama to themselves were positive.

The fact that preservice teachers comprehending the contribution of creative drama to their improvement include it in their educational programs in the future will enable children to reach information easier by supporting all the developments of children. Further, it will also contribute to such abilities of children as problem solving, cooperation, expressing oneself and sharing responsibilities.

Depending on these results, the followings can be recommended according to the special and the general:

- Teaching the course of creative drama at the faculties of education of universities by educators proficient in their fields will contribute students in expressing their feelings and thoughts in different ways, putting their own ideas forward in group activities and suggesting proposals for the solutions of problems,

- Besides including the course of creative drama in the program as a compulsory one, it can also be selected by the students as a selective course,

- Some topical creative drama ateliers can be carried out at universities at some certain interval in order to attract students and make them discuss over drama, 
- It can be supplied that the course of creative drama take place at all teaching programs other than teaching program of preschool education at universities,

- Preservice teachers can be led to such activities as seminars, panels, conferences, workshops, courses and ateliers etc. on the importance and usage of creative drama,

- Some research and application centers can be established for creative drama and studies can be supported in this field,

- More students can be reached by forming creative drama communities at universities. 
